Fake news: La verdad de las noticias falsas

Fake news: The truth about fake news

Fechas | En edición: 29/04/2020 - Publicación final: 01/07/2020

\title{
Álvaro JIMÉNEZ-RODRÍGUEZ
}

Universidad de Alicante. España. alvarojimenezrodriguez2@gmail.com

\section{Fake news: La verdad de las noticias falsas}

Editores: Marc AMORÓS-GARCIA

Barcelona: Plataforma, 2018.

194 páginas

ISBN: 978-84-17114-72-5

Ebook: 978-84-17114-73-2

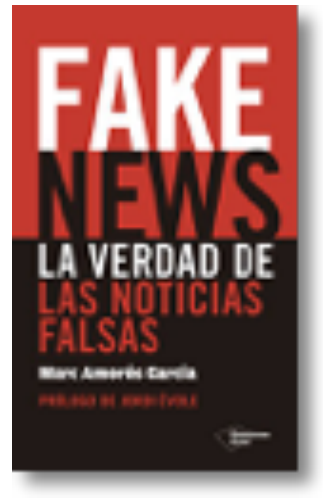

\section{Resumen}

Fake news: La verdad sobre las noticias falsas, estudia el paradigma en el que se encuentran las redes sociales y la proliferación de noticias falsas a través de ellas. La obra está dividida en treinta y nueve capítulos organizados en cinco partes, a través de los cuales, se muestra un análisis del negocio que generan las fake news, su uso por parte del poder político para generar opinión, o la facilidad de creencia que tienen en la sociedad, son algunos de los temas nombrados en esta obra, pionera hasta ahora en España, que lucha contra la desinformación que sufre la sociedad en un mundo, se supone, cada vez más informado.

\section{Palabras clave}

Clickbait; desinformación; fake news; mentiras; noticas; viral

\begin{abstract}
Fake news: The truth about fake news has an in-depth look at the model where the proliferation of fake news along with social media are found. The work is divided in thirty nine chapters which are organized in five parts. They show an analysis of the following: The business generating fake news, its use by the political authorities and how easily they make an impression on society. These are just some of the ideas named in this groundbreaking book, whose main aim is to fight against the lack of information the public is facing nowadays in a world that is supposed to be increasingly informed.
\end{abstract}

\section{Keywords}

Clickbait; disinformation; fake news; lies; news; viral 
El famoso periodista Marc Amorós lleva a cabo en su libro Fake news: La verdad de las noticias falsas un análisis sobre la divulgación producida a través de las redes sociales de numerosas noticias falsas. Basándose en ejemplos que van desde periódicos hasta la propia televisión, plantea debates, ejercicios de información y pone sobre la mesa una cuestión que cada vez más, inunda los noticiarios televisivos o forman parte de discursos políticos, como el del actual presidente de los Estados Unidos de América, Donald Trump.

Marc Amorós es licenciado en periodismo por la Universidad Autónoma de Barcelona y ha trabajado para diferentes medios, dirigiendo programas como Movistar +, La Sexta y TVE y trabajado para Antena 3, Tele 5, TV3, RNE, RAC 1 y la Cadena SER. Además de ser profesor universitario y orador, otorgando charlas sobre técnicas para descubrir una posible noticia falsa. El autor ha sido invitado a debates de diversa índole, como "Fake new \& Business", organizado por la Cátedra corporativa de la Universidad de Alicante o programas de televisión, entre ellos, "La mesa del Coronel" emitido en Cuatro.

De la mano de Jordi Évole, a través del prólogo, encontramos una pequeña introducción donde nos pone en situación de qué podemos encontrar en este libro, a través de experiencias vividas por él a lo largo de su carrera donde las fake news han sido protagonistas de escándalos o momentos que él mismo ha creado en televisión para dar visión a un problema como este. Con un toque más humorístico y cercano nos cuenta algunas noticias falsas relevantes para él y toca, de una manera sutil, temas de actualidad y políticos.

En el paradigma en el que podemos situar la sociedad actual, es de obligada reflexibilidad la relación que existe entre la desinformación viral y el uso que hacen los poderes políticos o medios de esa información falsa. El autor, a través del estudio de campo, nos muestra un catálogo de las numerosas noticas falsas que consiguieron mover el mundo y hacer creer a todo un país que dicha verdad, era en realidad, una creación falsa. Al comienzo del libro, en segundo capítulo llamado "Las fake news no son un juego" se pone a prueba al espectador haciéndole hacer un sencillo juego en el cual debe identificar la falsedad o veracidad de diez noticias que han sido emitidas en la vida real.

El estado de la cuestión va remitiendo a la intrínseca relación que existe entre las noticias falsas y las ventajas que obtienen de ellas diferentes fuerzas políticas para su propio beneficio. En la primera parte del libro se investiga de dónde surgen las fake news y quienes son los que sacan beneficio de su difusión, en muchas de esas ocasiones, no suele ser por dinero, sino únicamente por ideología política, otras veces, justamente a la inversa. A su vez, el autor nos da las pautas que deben seguirse para identificar una noticia de este tipo y los diferentes medios por donde suelen difundirse, a través de un análisis exhaustivo que va desde: un adolescente creando noticias falsas en su casa, hasta ser víctima de este tipo noticias.

Este tema se convierte en objeto de estudio a raíz de la llegada de Donal Trump a La Casa Blanca a través de este tipo de noticias, pero también, por el peligro que suponen todo esto para nuestra sociedad, ya que en numerosas ocasiones, esa información no veraz no queda únicamente en internet y es compartida, en ocasiones llevan a la gente a realizar actos vandálicos, como el ocurrido en contra de Hilary Clinton, nombrado también al comienzo del libro. Marc Amorós nos enseña los dos filos que encontramos en las redes sociales, la parte más positiva que conecta a la gente con su entorno digital y la parte más oscura, la que manipula a la población, una población que no está concienzada del problema que acarrea la divulgación de estas noticias, noticas que muchas veces, comparten sin haber contrastado esas fuentes y produciendo un efecto viral que termina contagiando y desmontado las ideas de otras personas.

La segunda parte de esta obra realiza un interesante análisis sociológico en el que la ciudadanía toma protagonismo. Nos enseña desde un punto de vista psicológico y social por qué las personas creemos dichas mentiras aunque muchas veces nuestro instinto nos dice que claramente es falso. Por otra parte, la nomenclatura de fake news hace hincapié en nuevos términos que cada vez más raído se están introduciendo en nuestra sociedad, términos como "burbuja política" o "sesgo ideológico" nos explican por qué motivo seguimos unas páginas en concreto, por qué eliminamos gente de nuestras cuentas por cuestiones ideológicas y sobre todo lo más importante: Por qué compartimos noticias únicamente leyendo titulares sin contrastar la información.

El periodismo también encuentra cabida en esta obra. Utilizando ejemplos de medios nacionales e internacionales se pone en cuestión la veracidad de periódicos de gran nombre que han sido engañados por fotografías o noticias falsas que han sido divulgadas en redes $\mathrm{u}$ otros periódicos y a consecuencia de ello han tenido que gastar muchas energías en volver a conseguir la buena fama que habían construido en el pasado. La sociedad ha cambiado en todas sus facetas, desde la forma de comunicarnos hasta la forma en la que consumimos información. Antes de la revolución 4.0, el consumo de información se obtenía a través del pago, actualmente, es extraño encontrar periódicos digitales que cobren por el consumo de sus noticias, crítica que el propia autor lleva a cabo en la tercera parte del libro, donde realiza 
una crítica constructiva en la que debemos pensar si este consumo gratuito de información de verdad nos ayuda a informarnos 0 , solamente alimenta el negocio del click más rápido por llegar a la noticia con un clickbait más apetecible a nuestros ojos. Nos plantea preguntas que debemos hacernos si queremos una sociedad verdaderamente informada y crítica, aunque en muchas de esas ocasiones, el precio de la verdad pueda ser renunciar a leer una noticia gratuita.

En resumen, la obra aquí reseñada abre un amplio debate social sobre la desinformación en pleno siglo $X X I$, el cual debería ser ejemplo de todo lo contrario, cada vez tener acceso a información más veraz y es popular por justamente lo opuesto. Supone una excelente revisión práctica de los usos nocivos y el mal uso de las redes sociales y las noticias a beneficio propia. Se pone en cuestión la tarea del periodista, el cual cada vez tiene más difícil y le es más complicado el poder contrastar toda la información que llega a sus manos. Una obra especialmente dedicada y que despertaría gran interés entre investigadores en comunicación, periodistas o cualquier persona que quiera saber más acerca de la posverdad y las consecuencias de las misma. Fake news: La verdad de las noticias falsas lleva a cabo un completo análisis de las noticias falsas más importantes a nivel mundial, nos muestra una sociedad cada vez más conectada, pero a la vez, más manipulable a través de titulares impactantes, que, verificados o no, son compartidos de manera masiva. 